\title{
Analytical Hierarchy Process for Developing a Building Performance-Risk Rating Tool
}

\author{
Natasha Khalil 1,2,a, Syahrul Nizam Kamaruzzaman² and Mohamad Rizal Baharum² \\ ${ }^{1}$ Faculty of Architecture, Planning and Surveying, Universiti Teknologi MARA Perak, 32610 Seri Iskandar, Perak, Malaysia \\ ${ }^{2}$ Faculty of Built Environment, Universiti Malaya, 50603 Kuala Lumpur, Malaysia
}

\begin{abstract}
The need to optimize the performance of buildings has increased consequently due to the expansive supply of facilities in higher education building (HEB). Proper performance assessment as a proactive measure may help university building in achieving performance optimization. However, the current maintenance programs or performance evaluation in the HEB is a systemic and cyclic process where maintenance is considered as an operational issue and not as opposed to a strategic issue. Hence, this paper proposed a Building Performance Risk Rating Tool (BPRT) as an improved measure for building performance evaluation by addressing the users' risk in health and safety aspects. The BPRT is developed from the result of a rating index using the Analytical Hierarchy Process (AHP) method. 12 facilities management (FM) experts and practitioners were involved in the rating process. The subjective weightings are analysed using the AHP computer software, the Expert Choice 11. The establishment of the BPRT was introduced as an aid of improvement towards the current performance assessment of HEB by emerging the concept of building performance and risk into a numerical strategic approach
\end{abstract}

\section{Introduction}

The development of higher education buildings (HEB) including expanding facilities is spirally a welcoming sign of the growth of tertiary educational programs. Unlike most land developers, university authorities need to have a long-term view of operations to ensure sustainability is achieved through performance optimization. However, building performance is not guaranteed as it depends on its lifespan and changing the physical requirement from the growing learning activities and students' populations. Hence, further issues such as space inefficiency, ventilation discomfort and inefficient of energy use may decrease the performance of the buildings from time to time [1]-[4]. Performance failure not only affects the building sustainability, but the users are also affected by the failure of building performance [5]. To optimise the performance of HEB, it should avoid allocating the occupants, visitors and passers-by at risk [6]. Several studies have shown that poor building performance presents vulnerability of risk towards the safety and health of building users [2], [7]-[13]. This demonstrates the significance of addressing risk in the building performance evaluation.

In revealing the crucial aspect of performance assessment, the government of Malaysia under the maintenance division has issued the General Circular (No.1) dated 27th March 2009, that states holistic management of asset through all management should undertake a systematic approach to achieving building

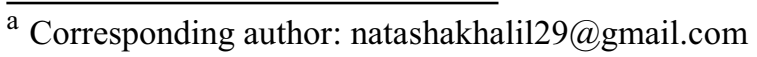

performance optimization. As described in the Guideline of Building Condition Assessment (BCA) to the existing government and public buildings [14] the assessment for a building is essential not only for building repairs and improvement, but the assessment must fit the aspect of safety and risk of building. The General Circular No. 2 (1995) by the government of Malaysia has also clearly states the responsibility of each head of the department to maintain and assess the in government and public buildings with an effective and systematic plan.

University buildings in Malaysia have been constructed since 1960. Nevertheless, all buildings deteriorate and decay with age as a result of various factors, including poor quality materials, bad workmanship, excessive usage, abuse as well as inadequate and poor maintenance [15], [16]. As buildings become larger and house more people, political and societal issues have become more complex, which in turn change the risks associated with occupying buildings [17]. Hence, indicating a list of criteria towards a proper building performance assessment is needed to mitigate hazards to the users.

\section{Building Performance and Risk Impact to the Users}

The basic concept of building performance evaluation (BPE) has been emerged on various issues, characteristics with various objectives. The performance concept involves recommendations for improvement and it is 
used for feedback and feed forward regarding the performance of similar buildings [18]. It denotes the comparison of client's goals and performance criteria against actual building performance, measured both subjectively and objective. Building performance has been defined in BS 5240 as "behaviour of a product in use" [7], [19]. It is also described as a process of assessing progress towards achieving goods and services efficiency, quality of building outputs and effectiveness of building operations [20]. This refers to the comprehensive features of a building, including structural, architectural, surroundings, environmental issues and building services. The performance measurement of a building is firstly summarised in terms of the background of the building and the scope of performance assessment [21]. Therefore, all relevant stakeholders need to understand the key performance factors in a building.

The aspect that needs to be thoroughly assessed in building performance depends on the evaluation purposes. The risk is associated with the unintended consequences of building performance and the primary cause of these risks may be a lack of measured performance data [22]. Risk approach advocates principles on the level of building performance and predicts the impact on society that is ultimately affected by the sources of risk. Therefore, risks in building performance can be framed as a health risk, safety risk, environmental risk, economic risk as well as political risk and others [7], [11], [23]. To suit with the aspects of building performance in Malaysian HEBs, health risk and safety risk become the main focus of this research. Hence, the following provide the description of health risk and safety risk in the context of study for this research:

\section{a) Health Risk}

Impact towards human health effects; either direct or indirect exposure of building factors that can cause health risk (latent or patent); the effect in short-term or long-term health suffers.

b) Safety Risk

The risk or hazards that create a tendency for injury, death, crime, theft, nuisance or burglary to the building users

Since the risk frames are focussed to health risk and safety risk, a list of performance elements or indicators needs to be constructed in prevailing the users' health and safety risk from poor performance elements.

\section{The Construct of Performance-Risk Indicators (PRI)}

The initial step in developing a new rating tool is to select the assessment areas that should be included and next, determine the parameters, attributes or indicators that can be used to measure the selected aspects [24], [25]. Analysis of the previous established performance rating tools such as Building Research Establishment's Environmental Assessment Method (BREEAM), Leadership in Energy and Environmental Design (LEED), Total Building Performance (TBP), Building
Safety Condition Index (BSCI), Building Safety Condition Index (BSCI) and Building Health Hygiene Index (BHHI) is carried out in the literature stage. The review is considered by far the most comprehensive method to develop a new rating scheme and to examine sustainability issues [25]. The construct indicators were initially compiled from the existing performance and green rating tools and also precedent research relating to building performance [2], [7], [8], [10]-[12], [17], [26][29].

The initial construct of indicators, named as Performance-Risk Indicators (PRI) was further confirmed through a preliminary survey, using semi-structured interview technique. 18 building managers and operators in local university buildings were involved in the interview and their input is needed to obtain suitability of the listed indicators for building performance rating assessment to be used in the Malaysian HEBs. The findings of the interview have finalised 26 indicators that are categorized into the performance elements of functional performance, technical and indoor environmental performance. Table 1 depicts the final framework of the construct PRI. The listed indicators are confirmed as the predictor variables that can contribute to the performance level and the users' health and safety risk. The PRI constructs constitute the preliminary basis of a framework for further development of the proposed building performance-risk rating tool. It will be developed further with relative importance and assigned weights for each PRI in the next stage using Analytical Hierarchy Process (AHP) as decision-making approach.

Table 1. The construct of PRI based from the result of preliminary survey.

\begin{tabular}{|c|c|}
\hline $\begin{array}{l}\text { Performance } \\
\text { Elements }\end{array}$ & Performance-Risk Indicators (PRI) \\
\hline \multirow{10}{*}{$\begin{array}{l}\text { Functional } \\
\text { Performance }\end{array}$} & Spaces \\
\hline & Orientation \\
\hline & Infrastructure \\
\hline & Access/entrance \\
\hline & Circulation area \\
\hline & Ergonomic building facilities \\
\hline & Adequacy of building signage \\
\hline & Emergency exits \\
\hline & $\begin{array}{l}\text { Building-related illnesses/sick building } \\
\text { syndrome }\end{array}$ \\
\hline & Amenities \\
\hline \multirow{9}{*}{$\begin{array}{l}\text { Technical } \\
\text { Performance }\end{array}$} & Design of building fittings \\
\hline & Structural stability \\
\hline & Information Technology systems operations \\
\hline & Electrical services \\
\hline & Plumbing services \\
\hline & Fire Prevention Services \\
\hline & Materials \& Internal Finishes \\
\hline & Roof \\
\hline & Lift \\
\hline \multirow{6}{*}{$\begin{array}{l}\text { Indoor } \\
\text { Environmental } \\
\text { Performance }\end{array}$} & Cooling (Thermal comfort) \\
\hline & Artificial lighting (Visual comfort) \\
\hline & Natural lighting (Visual comfort) \\
\hline & Waste reduction \\
\hline & Building ventilation \\
\hline & Acoustic comfort (Noise) \\
\hline
\end{tabular}




\section{Level of cleanliness}

\section{Methodology}

This research adopts a quantitative approach using questionnaires consisting the Analytical Hierarchy Process (AHP), as the main instrument. The list of PRI was incorporated into the questionnaire as survey questions. Since AHP method relies on experts' judgment to moderate feedback throughout the process. therefore, the respondents are the facilities management (FM) practitioners from the public and private organizations. The sampling was drawn based on purposive samples with predetermined criteria and also with the help of Malaysian Association of Facility Managers (MAFM). Respondents were selected based on purposive sampling, with predetermined criteria that requires the experts (the respondents) to possess experience or involvement in any project related to the educational buildings with at least 10 years' working experience. Hence, the list of potential respondents is shortlisted to 22 experts. The experts are from different fields such as architecture, engineering, surveying, facilities management and internationl business studies. In this process, it requires the experts to provide justification on the importance of the construct indicators and also the rating process of weighted for each parameter. After the judgement is completed, the ranking of indicators is arranged according to the highest order to the lowest order of importance. A final set of weighted assigned for each indicator is presented at the end of stages.

\subsection{Application of Analytical Hierarchy Process}

In dealing with such a multi-criteria decision-making process, the Analytic Hierarchy Process (AHP) developed by Dr. Thomas L. Saaty in 1977, is used for this study. AHP allowed the experts to evaluate the attribute weightings with greater consistency through pairwise comparisons. The AHP is a theory of measurement through pairwise comparisons and relies on the judgements of experts to derive priority scales [30][33]. In AHP, all criteria or parameters are assigned with the weight score that shows the importance of each criterion. The AHP approach has been widely adopted in the built environment fields as decision-making tool [25], [34]-[36]. Existing performance schemes and rating tools such as LEED, BHHI and BSCI also adopted the process of AHP to develop hierarchy or rating tool [35], [37]. It is also found that AHP is used to assess risk in a supply chain [38]. Therefore, the application of AHP for this survey is robust and do not constitute any bias result as the judgment on the weighted depending on the experts' decision. Moreover, the methodology of the AHP allows for the internal consistency of the respondent's results to be checked.
A letter of invitation and the sample sets of a questionnaire are firstly distributed to the shortlisted respondents. Out of total 22 experts, 12 experts are willing to participate in the survey and the rate of response to this survey is $54.6 \%$. Before beginning with the survey, the researcher introduced the purpose of the survey to the respondents and showed all sections involved in the survey forms. A detail explanation was conveyed to the respondents for the application of AHP as the process is not aware by most of the respondents. The weightings of the building factors were assessed using nine (9) scales of importance [30], [31], as shown in Table 2. The respondents' weightings of the different factors were extracted from a pairwise comparison of the relative importance of all pairs of factors using the AHP computer software package Expert Choice 11 version 3.01 .

Table 2. AHP scale of importance [30], [31]

\begin{tabular}{|c|c|}
\hline $\begin{array}{c}\text { AHP SCALE OF } \\
\text { IMPORTANCE }\end{array}$ & DESCRIPTION \\
\hline 1 & Equal Importance \\
\hline 2 & Equally to Moderately \\
\hline 3 & Moderate Importance \\
\hline 4 & Moderately to Strong \\
\hline 5 & Strong Importance \\
\hline 6 & Strongly to Very Strong \\
\hline 7 & Very strong Importance \\
\hline 8 & Very strong to Extremely \\
\hline 9 & Extreme Importance \\
\hline
\end{tabular}

The experts are required to compare the importance between two pairwise indicators and rate the scale of importance of the chosen indicator. Comparison of importance for each indicator is rated using the values of importance 1-9 scale (as shown in Table 2).

\section{Analysis of Results and Discussion}

\subsection{The AHP weightings}

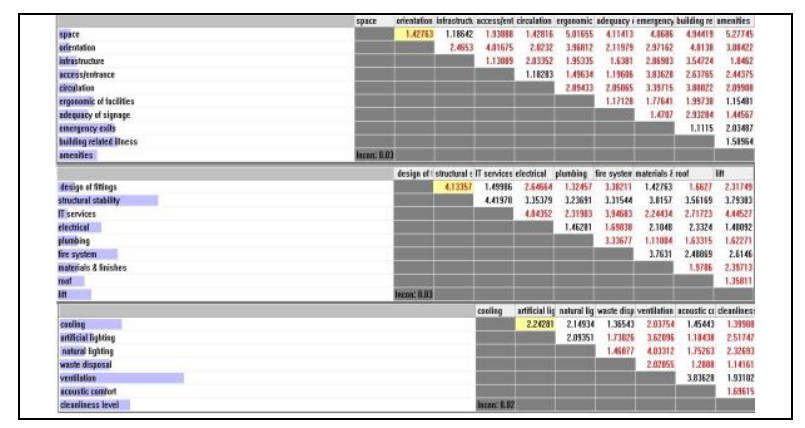

\subsection{Administration of Survey}




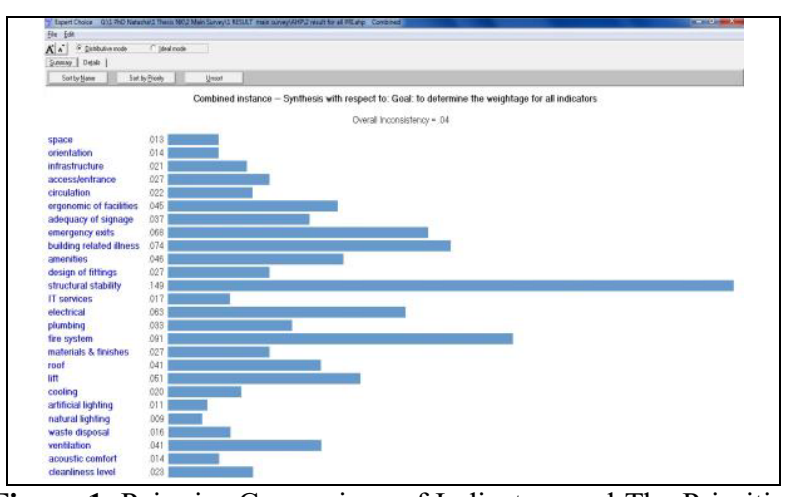

Figure 1. Pairwise Comparison of Indicators and The Priorities of Indicators, Using the Expert Choice 11

The relative importance (relative weight) of each category and each indicator within each category was established using a square matrix structure. For each category and indicator, the weight was calculated by the geometric mean of values of questionnaires filled by the experts who participated in the survey. The final step in the process combined the ratings of the criteria to form an overall rating for each decision alternative. The numerical pairwise comparison and the priorities of indicators obtained by combining the overall judgment from the 12 experts is shown in Figure 1. To obtain the priorities of indicators, the distributive mode is chosen as it normalizes alternative scores under each criterion so that they sum to one (1.00). This creates a dependency on how well all other alternatives perform and hence the potential for rank reversal. It shows that the internal consistency ratio (CR) .04 where in AHP, the CR must be less than $0.1(10 \%)$ [31]. Therefore, the data is reliable and achieves consistency.

Table 3. Summary of Relative Weights for Performance Elements and Performance-Risk Indicators

\begin{tabular}{|c|c|c|c|}
\hline $\begin{array}{c}\text { PERFORMANCE } \\
\text { ELEMENTS } \\
\text { (PE) }\end{array}$ & $\begin{array}{c}\text { PERFORMANCE- } \\
\text { RISK INDICATORS } \\
\text { (PRI) }\end{array}$ & $\begin{array}{l}\text { WEIGHT } \\
(\%)\end{array}$ & RANKING \\
\hline \multirow{2}{*}{$\begin{array}{c}\text { Functional } \\
\text { Performance }\end{array}$} & Spaces & 1.3 & 23 \\
\hline & Orientation & 1.4 & 24 \\
\hline \multirow[t]{8}{*}{$36.7 \%$} & Infrastructure & 2.1 & 18 \\
\hline & Access/entrance & 2.7 & 14 \\
\hline & Circulation area & 2.2 & 17 \\
\hline & $\begin{array}{l}\text { Ergonomic building } \\
\text { facilities }\end{array}$ & 4.5 & 8 \\
\hline & $\begin{array}{l}\text { Adequacy of building } \\
\text { signage }\end{array}$ & 3.7 & 11 \\
\hline & Emergency exits & 6.8 & 4 \\
\hline & $\begin{array}{l}\text { Building-related } \\
\text { illnesses/ SBS }\end{array}$ & 7.4 & 3 \\
\hline & Amenities & 4.6 & 7 \\
\hline \multirow[t]{9}{*}{$\begin{array}{c}\text { Technical } \\
\text { Performance }\end{array}$} & $\begin{array}{l}\text { Design of building } \\
\text { fittings/fixtures }\end{array}$ & 2.7 & 15 \\
\hline & Structural stability & 14.9 & 1 \\
\hline & IT systems operations & 1.7 & 20 \\
\hline & Electrical services & 6.3 & 5 \\
\hline & Plumbing services & 3.3 & 12 \\
\hline & $\begin{array}{l}\text { Fire Prevention } \\
\text { Services }\end{array}$ & 9.1 & 2 \\
\hline & $\begin{array}{l}\text { Materials \& Internal } \\
\text { Finishes }\end{array}$ & 2.7 & 13 \\
\hline & Roof & 4.1 & 9 \\
\hline & Lift & 5.1 & 6 \\
\hline
\end{tabular}

\begin{tabular}{|c|l|c|c|}
\hline $\begin{array}{c}\text { Indoor } \\
\text { Environmental } \\
\text { Performance }\end{array}$ & $\begin{array}{l}\text { Cooling (Thermal } \\
\text { comfort) }\end{array}$ & 2.0 & 19 \\
\cline { 2 - 4 } $13.4 \%$ & Artificial lighting & 1.1 & 25 \\
\cline { 2 - 4 } & Natural lighting & 0.9 & 26 \\
\cline { 2 - 4 } & Waste disposal & 1.6 & 21 \\
\cline { 2 - 4 } & Building ventilation & 4.1 & 10 \\
\cline { 2 - 4 } & Acoustic comfort & 1.4 & 22 \\
\cline { 2 - 4 } & Level of cleanliness & 2.3 & 16 \\
\hline
\end{tabular}

To ease the calculation of weight for each performance element, the result from the combined synthesis of each indicator is illustrated in Table 3 . The weightings in Table 3 shows that structural stability is ranked as the most important indicator, with a global weight $14.9 \%$, and followed by fire prevention services (9.1\%), building-related illnesses $(7.4 \%)$, emergency exits $(6.8 \%)$ and electrical services $(6.3 \%)$. This suggests that five indicators become the top important factors to be well performed in building performance, as it may generate larger impact towards the users" health and safety risk. This has suggested that the focus on building performance and user's risk on the priority of the indicator structural stability is more significant than other 25 indicators. This is supported by previous studies [39][43] that described structural degradation and deterioration causes impact on performance quantification in terms of collapse safety and health of the users. Structural elements are among the important safety factors for performance assessment [44]. The structural stability of a building must be inspected and maintained from time to time in order to ensure the occupants' safety [16]. Hazards in the built environment were closely related to accidents occurring in buildings; therefore, the occupants must be safeguarded against hazards arising from structural failure.

With respect to the result of the Expert Choice, it shows that the weightings for functional performance, technical performance and indoor environmental performance are $36.7 \%, 49.9 \%$ and $13.4 \%$, respectively. This insinuates that technical performance was a bit more important than functional performance and indoor environmental performance. The discussion of the findings is further explained in the following section

\subsection{Discussion of result}

It can be summarised that the attained weightings for the technical performance suits with the support from the academic theories and literature on the importance of building technical performance.The significant finding based on the summated score is that technical performance is considered as the most critical performance elements that place greater impact in the context of building performance and users' risk. Inevitably, the performance assessment of technical performance in a building becomes a crucial measure. The need for continuous monitoring of the technical performance of buildings over their lifetime becomes obvious since buildings are not operatively static [45]. Technical performance aspects of a building complete the functionality aspect, therefore, a building may succeed in achieving a high level of functionality if able to meet 
prescribed technical standards. The performance requirements for building need to match with the provision of reliable information about the alternatives, including technical specifications with indications of service life and performance over time [46].

The empirical findings of this study indicate that the PRIs have significant difference based on the judgment by the panel of experts. The results suggest that the relevant stakeholders in the facility or maintenance management of higher educational buildings should pay greater attention to the priority of indicator that has significant risk impact, ideally the top priority indicators. This is also has supported studies by [47]-[49] that described the maintenance organisation in university buildings must look far beyond the immediate objectives of the products or services to the users. Since the performance evaluation in university buildings is under the responsibility of facility or maintenance unit, information on the building performance should be well documented in a safe register.

\section{Development of the Building Performance-Risk Rating Tool (BPRT)}

The result of weightings has successfully helped to establish the further development of the building performance risk rating tool for this study. Hence, the proposed building performance risk rating tool (BPRT) is proposed as an improved method to carry out building condition survey. The steps and process in the proposed BPRT adapt the steps from the existing performance and rating tool such as GBI, BARIS and SABA. There are three (3) steps included in the proposed BPRT. The first step requires the building assessors to evaluate the performance and risk of the indicators, and the second step comprises the overall score for PRI. The third step shall be the final process of assessment where the assessed building is classified into a rating classification. The description of the steps and process are entailed as follows:

\subsection{Step 1: Evaluation of performance and risk for each indicator}

In this step, the evaluation of performance and risk indicators shall be carried out as to capture the performance grading of the building. Hence, the assessment outcome which is known as performance risk assessment score suggested five scales, that ranges from 0.2 to 1.0 . If the score achieves 1.0 , it generally defined that the indicator is in an excellent performance that definitely presents insignificant risk impact to the users. Table 4 shows the score and description for the scales. The description of scale for the performance risk assessment was adopted and modified from the assessment of BARIS [14], [50] and also previous studies relating to risk in building assessment [29], [51], [52].

Table 4. Scale and Description for Performance-Risk Assessment Score for each indicator

\begin{tabular}{|c|c|c|}
\hline SCALE & \multicolumn{1}{c|}{ DESCRIPTION OF SCALE } \\
\hline \multirow{2}{*}{0.2} & $\begin{array}{l}\text { Poor performance with catastrophic building } \\
\text { defects } \\
\text { Catastrophic: Present risk that results in multiple } \\
\text { fatalities; may result in human death or serious } \\
\text { injury/illness }\end{array}$ \\
\hline 0.4 & $\begin{array}{l}\text { Low performance with major building defects } \\
\text { - }\end{array}$ \\
\hline & $\begin{array}{l}\text { Significant risk: Present risk towards serious or } \\
\text { fatal injury to occupants or major injury/illness }\end{array}$ \\
\hline 0.6 & $\begin{array}{l}\text { Medium performance with moderate building } \\
\text { defects }\end{array}$ \\
\hline 0.8 & $\begin{array}{l}\text { High risk: Present risk towards significant impact } \\
\text { with minor injury or minor occupational illness }\end{array}$ \\
\hline 1.0 & $\begin{array}{l}\text { Good performance with minor building defects } \\
\text { Medium risk: Present risk towards minor physical } \\
\text { discomfort to occupants or minor occupational } \\
\text { illness }\end{array}$ \\
\hline & $\begin{array}{l}\text { Excellent performance with little building defects } \\
\text { Low risk: Present risk that the impact is } \\
\text { insignificant; minimal impact or no apparent } \\
\text { impact at all }\end{array}$ \\
\hline
\end{tabular}

During the assessment, the performance of each indicator was rated in accordance with the above PR score. Hence, Figure 2 shows the extracted steps of assessment using the assessment score and the weightings.

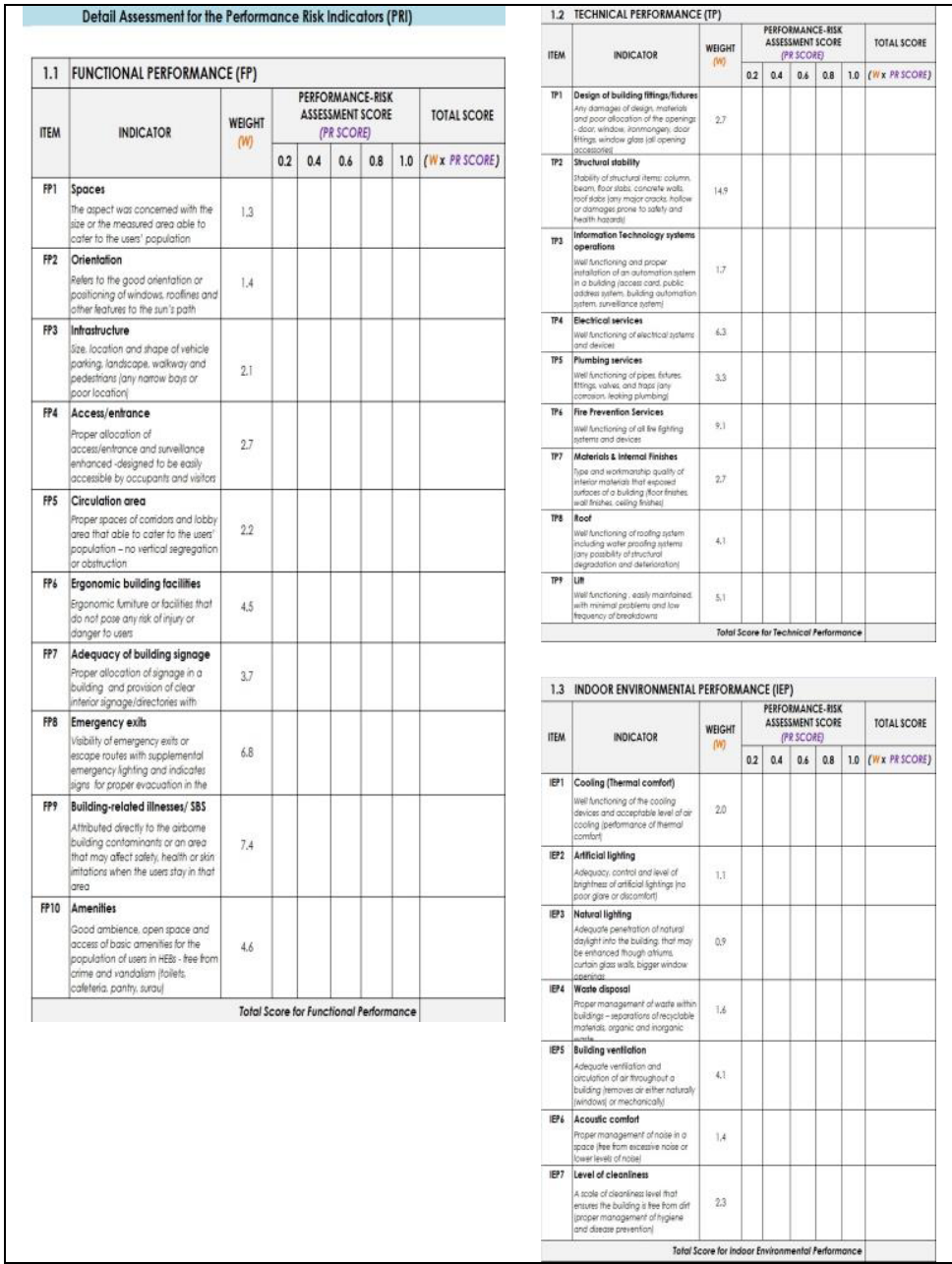

Figure 2. Steps During the Performance Assessment using the Assessment Score and Weightings 


\subsection{Step 2: Overall Score for Performance Risk Indicators (PRI)}

As mentioned in step 1, the performance of each indicator is evaluated using a performance risk assessment score that ranges from 0.2 to 1.0 . Then, the obtained score is multiplied by the weighting assigned to each indicator. The total of overall PRI score generates the score of performance elements (functional performance, technical performance and indoor environmental performance). Once the performance assessment of all indicators completed, the overall score of PRI can be calculated by summing up each of the PRI scores. This will generate the overall score of performance elements, in accordance with the category of functional performance, technical performance and indoor environmental performance. Since each of the performance elements is assigned with maximum weight that is derived from the result of AHP, the score that shall be obtained from the performance assessment shall not be more than the maximum weight. The maximum weightings for functional performance are $36.7 \%$, technical performance is $49.9 \%$ and indoor environmental performance is $13.4 \%$.

\subsection{Step 3: The Performance-Risk Rating Classification}

The final step in the performance assessment using the building performance risk rating tool (BPRT) is to determine the rating classification of the assessed building. The rating classification shall generate the performance grade and the level of risk. There are five ratings that determine the final performance measurement of the assessed building either in "Excellent", "Good", "Medium", "Low" and "Poor", as shown in Table 5. The determinants of the rating classification depend on the final score attained from the performance assessment to all indicators. The classification of the rating is adopted from the existing performance and green rating tools such as GBI and BARIS. However, the description of each rating is modified from previous studies relating to risk in building assessment [29], [51], [52] to suit with the context of performance and risk in this study. The final risk classification shall help the building assessors to rectify areas concerning performance failure and its possible impact on building users. Thus, it helps the management to plan further actions on mitigating or reducing the risk through performance improvement.

Table 5. Performance-Risk Rating Classification

\begin{tabular}{|c|l|c|}
\hline $\begin{array}{c}\text { TOTAL } \\
\text { PERFORMANCE } \\
\text { ELEMENTS } \\
\text { SCORE }\end{array}$ & RATING & DESCRIPTION \\
\hline $80-100$ & Excellent & $\begin{array}{c}\text { Excellent building } \\
\text { performance with low } \\
\text { impact to the users' risk on } \\
\text { health and safety }\end{array}$ \\
\hline $60-79$ & Good & $\begin{array}{c}\text { Good building performance } \\
\text { with medium impact to the } \\
\text { users' risk on health and } \\
\text { safety }\end{array}$ \\
\hline
\end{tabular}

\begin{tabular}{|c|l|c|}
\hline $41-59$ & Medium & $\begin{array}{c}\text { Medium building } \\
\text { performance with high } \\
\text { impact to the users' risk on } \\
\text { health and safety }\end{array}$ \\
\hline $31-40$ & Low & $\begin{array}{c}\text { Low building performance } \\
\text { with significant impact to } \\
\text { the users' risk on health and } \\
\text { safety }\end{array}$ \\
\hline $20-30$ & Poor & $\begin{array}{c}\text { Poor performance building } \\
\text { with catastrophic impact to } \\
\text { the users' risk on health and } \\
\text { safety }\end{array}$ \\
\hline
\end{tabular}

With the proposed BPRT through this study, it shall be useful to the building operators in Malaysian HEBs to assess the condition of the academic building that concerns on both performance and the users' risk. Surveys that employ ratings instead of descriptions are gaining wide acceptance in the industry because they cater to the need for numerical analysis output [15]. Through the application of the BPRT as proposed in this study shall initiate an improved proactive procedure for performance assessment and maintenance in HEB

\section{Conclusion}

By integrating criteria from different assessment methodological frameworks, this research builds on the strengths of each and provides a more holistic assessment approach among careful attention to local context. The proposed BPRT granted robust information on the level of risk towards the building users. The students, the academicians, administration staffs and the supporting personnel are the entity or group of individuals in HEB. The building users can be presented with a warranty that the building fulfills the performance optimization with a precise risk level in terms of health and safety aspects. These two aspects of risk become the most crucial information that needs to be conveyed to the users and without a proper assessment, users are deemed to accept the risk without knowing the impact that may jeopardize their health and safety. This tool is also potential to extend its application to the other types of buildings since the performance criteria are related to the functional, technical and indoor environmental elements of a building.

\section{Acknowledgment}

The authors wish to acknowledge the support of funding for this research under the Exploratory Research Grant Scheme (ERGS) Phase 1/2013 from Ministry of Higher Education (MOHE), Malaysia

\section{References}

1. A. Gillen, A. Wright, and L. Spink, "Student perceptions of a positive climate for learning: a case study," Educ. Psychol. Pract., vol. 27, no. 1, pp. 6582, Mar. 2011.

2. H. Altan, "Energy efficiency interventions in UK higher education institutions," Energy Policy, vol. 38, no. 12 , pp. 7722-7731, Dec. 2010. 
3. M. Sapri and S. Muhammad, "Monitoring energy performance in higher education buildings for sustainable caumpus," Malaysian J. Real Estate, vol. 5, no. 1, pp. 1-25, 2010.

4. M. A. Hassanain, "Post-Occupancy Indoor Environmental Quality Evaluation of Student Housing Facilities," Archit. Eng. Des. Manag., vol. 3, no. 4, pp. 249-256, 2007.

5. A. L. Olanrewaju, M. F. Khamidi, and A. Idrus, "Quantitative analysis of defects in Malaysian university buildings: Providers ," J. Retail Leis. Prop., vol. 9, no. 2, pp. 137-149, 2010.

6. D. Amaratunga and D. Baldry, "Building Performance Evaluation In Higher Education Properties: Towards A Process Model," in Construction and Building Research Conference (COBRA) 1999, 1999, pp. 45-56.

7. N. Almeida, V. Sousa, L. Alves Dias, and F. Branco, "A framework for combining risk-management and performance-based building approaches," Build. Res. Inf., vol. 38, no. 2, pp. 157-174, Apr. 2010.

8. R. J. Cole, "Building environmental assessment methods : assessing construction practices," Constr. Manag. Econ., vol. 18, no. 8, pp. 949-957, 2000.

9. T. Lützkendorf and D. Lorenz, "Integrating sustainability into property risk assessments for market transformation," Build. Res. Inf., vol. 35, no. 6, pp. 644-661, Nov. 2007.

10. T. Lützkendorf and D. P. Lorenz, "Using an integrated performance approach in building assessment tools," Build. Res. Inf., vol. 34, no. 4, pp. 334-356, Jul. 2006.

11. B. J. Meacham, "Risk-informed performance-based approach to building regulation," J. Risk Res., vol. 13, no. 7, pp. 877-893, Oct. 2010.

12. A. Wolski, N. A. Dembsey, and B. J. Meacham, "Accommodating perceptions of risk in performancebased building 're-safety' code development," Fire Saf. J., vol. 34, pp. 297-309, 2000.

13. A. Zalejska-Jonsson, "Evaluation of low-energy and conventional residential buildings from occupants' perspective," Build. Environ., vol. 58, pp. 135-144, Dec. 2012.

14. Public Works Department, Garis Panduan Pemeriksaan Dan Penilaian Keadaan Bangunan Sedia Ada (JKR 21602 - 0004 - 13), JKR 21602-. Bahagian Senggara Fasiliti Bangunan, Cawangan Kejuruteraan Senggara Ibu Pejabat JKR Malaysia, 2013.

15. A. I. Che-Ani, A. S. Ali, M. M. Tahir, N. A. G. Abdullah, and N. M. Tawil, "The Development of a Condition Survey Protocol (CSP) 1 Matrix for Visual Building Inspection," in The Construction, Building and Real Estate Research Conference of the Royal Institution of Chartered Surveyors (COBRA2010), 2-3 September 2010, 2010, pp. 8-22.

16. A. S. Ali, S. N. Kamaruzzaman, R. Sulaiman, and Y. C. Peng, "Factors affecting housing maintenance cost in Malaysia," J. Facil. Manag., vol. 8, no. 4, pp. 285298, 2010.

17. B. P. Thompson and L. C. Bank, "Risk Perception in Performance-Based Building Design and Applications to Terrorism-Resistant Design," no. February, pp. 6169, 2007.

18. D. Amaratunga and D. Baldry, "Appraising the total performance of higher education buildings: A participator y approach towards a knowledge- base system," in Construction and Building Research Conference 1998: Proceedings (COBRA) 2nd-3rd September 1998, Oxford Brookes University, 1998, pp. $1-17$.

19. J. Douglas, "Building performance and its relevance to facilities management," Facilities, vol. 14, no. April, pp. 23-32, 1996.

20.D. Amaratunga and D. Baldry, "A conceptual framework to measure facilities management performance," Prop. Manag., vol. 21, no. 2, pp. 171189, 2003.

21. G. McDougall, J. R. Kelly, J. Hinks, and U. S. Bititci, "A review of the leading performance measurement tools for assessing buildings," J. Facil. Manag., vol. 1, no. 2, pp. 142-153, 2002.

22. J. E. Woods, "Expanding the Principles of Performance to Sustainable Buildings," Real Estate Issues, vol. 33, no. 3, pp. 37-46, 2008.

23. B. Meacham, R. Bowen, J. Traw, and A. Moore, "Performance-based building regulation: current situation and future needs," Build. Res. Inf., vol. 33, no. 2, pp. 91-106, Mar. 2005.

24. T. Malmqvist and M. Glaumann, "Environmental efficiency in residential buildings - A simplified communication approach," Build. Environ., vol. 44, no. 5, pp. 937-947, May 2009.

25. H. H. Ali and S. F. Al, "Developing a green building assessment tool for developing countries - Case of Jordan," Build. Environ., vol. xxx, no. 2008, pp. 1-12, 2008.

26. M. Camilleri, R. Jaques, and N. Isaacs, "Impacts of climate change on building performance in New Zealand," Build. Res. Inf., vol. 29, no. 6, pp. 440-450, Nov. 2001.

27. E. Meins, H. Wallbaum, R. Hardziewski, and A. Feige, "Sustainability and property valuation: a riskbased approach," Build. Res. Inf., vol. 38, no. 3, pp. 280-300, Jun. 2010.

28. R. Spence, "Risk and regulation: can improved government action reduce the impacts of natural disasters?," Build. Res. Inf., vol. 32, no. 5, pp. 391402, Sep. 2004.

29. R. N. Whitfield, "Managing Institutional Risks - A Framework," University of Pennsylvania, 2003.

30. T. L. Saaty, "Decision making with the analytic hierarchy process," Int. J. Serv. Sci., vol. 1, no. 1, pp. 83-98, 2008.

31. T. L. Saaty, "How to make a decision: The Analytic Hierarchy Process," Eur. J. Oper. Res., vol. 48, pp. 9 26, 1990.

32. M. Alexander, "Decision-Making using the Analytic Hierarchy Process (AHP) and SAS / IML ®," in SESUG 2012, 2012, pp. 1-12.

33. K. Bunruamkaew, "How to do AHP analysis in Excel The Analytical Hierarchy Process - AHP," 2012.

34. Z. Chen, D. Clements-croome, J. Hong, H. Li, and Q. $\mathrm{Xu}$, "A multicriteria lifespan energy efficiency 
approach to intelligent building assessment," Energy Build., vol. 38, pp. 393-409, 2006.

35. C. A. Poveda and M. Lipsett, "A Review of Sustainability Assessment and Sustainability/Environmental Rating Systems and Credit Weighting Tools," J. Sustain. Dev., vol. 4, no. 6, pp. 36-55, Nov. 2011.

36. T. Hsieh, S. Lu, and G.-H. Tzeng, "Project Fuzzy MCDM approach for planning and design tenders selection in public office buildings," Int. J. Proj. Manag., vol. 22, pp. 573-584, 2004.

37. D. C.-W. Ho, K.-W. Chau, A. King-Chung Cheung, Y. Yau, S.-K. Wong, H.-F. Leung, S. Siu-Yu Lau, and W.-S. Wong, "A survey of the health and safety conditions of apartment buildings in Hong Kong," Build. Environ., vol. 43, no. 5, pp. 764-775, May 2008.

38. I. N. Pujawan and L. H. Geraldin, "House of risk: a model for proactive supply chain risk management," Bus. Process Manag. J., vol. 15, no. 6, pp. 953-967, 2009.

39. M. Clift, "Building quality assessment (BQA) for offices," Struct. Surv., vol. 14, no. 2, pp. 22-25, 1996.

40. G. Baird, J. Gray, N. Isaacs, D. Kernohan, and G. McIndoe, Building Evaluation Technique. McGrawHill: New York, NY, USA, 1996.

41. H. Abdul-Rahman, C. L. Kwan, and P. C. Woods, "Quality function deployment in construction design: application in low-cost housing design," Int. J. Qual. Reliab. Manag., vol. 16, no. 6, pp. 591-605, 1999.

42. A. M. M. Liu, "The quest for quality in public housing projects : a behaviour-to-outcome paradigm," Constr. Manag. Econ., vol. 21, pp. 147-158, 2003.

43. A. T. Goh and Y. Ahmad, "Public Low-Cost Housing In Malaysia : Case Studies On Ppr Low-Cost Flats In Kuala Lumpur," Kuala Lumpur, 2012.

44. H. N. Husin, A. H. Nawawi, F. Ismail, and N. Khalil, "Preliminary Survey of Integrated Safety Elements into Post Occupancy Evaluation for Malaysia' s Low Cost Housing," Procedia - Soc. Behav. Sci., vol. 36, no. June 2011, pp. 583-590, 2012.

45. G. Augenbroe and C.-S. Park, "Quantification methods of technical building performance," Build. Res. Inf., vol. 33, no. 2, pp. 159-172, Mar. 2005.

46. W. Trinius and C. Sjöström, "Service life planning and performance requirements," Build. Res. Inf., vol. 33, no. 2, pp. 173-181, Mar. 2005.

47. A. L. Olanrewaju, "Quantitative Analysis of Criteria in University Building Maintenance in Malaysia," Australas. J. Constr. Econ. Build., vol. 10, no. 3, pp. 51-61, 2010.

48. A. L. Olanrewaju, M. F. Khamidi, and A. Idrus, "Building Maintenance Management in a Malaysian University Campuses: A Case Study," Australas. J. Constr. Econ. Build., vol. 10, no. 1/2, pp. 76-89, 2010.

49. A. L. Olanrewaju, "Case for alternative approach to building maintenance management of public universities," J. Build. Apprais., vol. 5, no. 3, pp. 201-212, 2010.
50. Integrated Asset Planning Branch (CPAB), "Sesi 1: Pengenalan dan Keperluan Building Condition Assessment (BCA)," 2015.

51.P. Massingham, "Knowledge risk management: a framework," J. Knowl. Manag., vol. 14, no. 3, pp. 464-485, 2010.

52.] P. X. W. Zou, S. Redman, and S. Windon, "Case Studies on Risk and Opportunity at Design Stage of Building Projects in Australia: Focus on Safety," Archit. Eng. Des. Manag., vol. 4, no. 3, pp. 221-238, 2008. 